\title{
Remediation of salt-affected soil by the addition of organic matter - an investigation into improving glutinous rice productivity
}

\author{
Suriyan Cha-um*, Chalermpol Kirdmanee \\ NSTDA/BIOTEC - National Center for Genetic Engineering and Biotechnology, 113 Thailand Science Park, \\ Phaholyothin Road, Klong 1, Klong Laung, Pathumthani, 12120 - Thailand. \\ *Corresponding author < suriyanc@biotec.or.th> \\ Edited by: Leonardo Oliveira Medici
}

\begin{abstract}
Soil salinity may limit plant growth and development, and cause yield loss in crop species. This study aimed at remediating saline soil using organic matter $(\mathrm{OM})$ treatment, before the cultivation of RD6 rice (Oryza sativa L. spp. indica). Physiological and morphological characters of rice plants, as well as crop yield, were evaluated from salt-affected soil with varying levels of salinity. The chlorophyll $a$ and total chlorophyll pigments of rice plants grown in salt-affected soil ( $2 \%$ salt level) with the application of OM were maintained better than in plants grown without OM treatment. The degree of reduced photosynthetic pigments in rice plants was dependent on the level of salt contamination. Pigment content was positively related to maximum quantum yield of PSII $\left(\mathrm{F}_{\mathrm{v}} / \mathrm{F}_{\mathrm{m}}\right)$ and quantum efficiency of PSII $\left(\Phi_{\mathrm{PSII}}\right)$, leading to reduced net photosynthetic rate $\left(P_{\mathrm{n}}\right)$ and reduced total grain weight (TGW). Photosynthetic abilities, including chlorophyll $a$ and total chlorophyll pigments and $\Phi_{\mathrm{PSII}}$, in rice plants grown with OM treatment were greater than in those cultivated in soil without the OM treatment, especially in high salt levels (1-2\% salt). The remediation of salt-affected soil in paddy fields using OM should be applied further, as an effective way of enhancing food crop productivity.

Keywords: chlorophyll a fluorescence, inland salinity, pigment stabilization, net photosynthetic rate, yield
\end{abstract}

\section{Introduction}

Soil salinity (electrical conductivity - ECe $>4 \mathrm{dS} \mathrm{m}^{-1}$ ) is a major abiotic stress which limits plant growth and development, causing yield loss in crop species, which are defined as glycophyte or salt susceptible (Hasegawa et al., 2000; Qadir et al., 2007). Salt-affected soils are identified by excessive levels of water-soluble salts, especially sodium chloride $(\mathrm{NaCl})$ (Tanji, 2002). $\mathrm{NaCl}$, a major salt contaminant in soil, is a small molecule which when ionized by water, produces sodium $\left(\mathrm{Na}^{+}\right)$and chloride $\left(\mathrm{Cl}^{-}\right)$ions. These toxic ions cause ionic and osmotic stress at the cellular level in higher plants, especially in susceptible or glycophyte species (Mansour and Salama, 2000; Chinnusamy et al., 2005). There are many effective ways for improving salt-affected land, such as water leaching, chemical remediation and phytoremediation (Ahmad and Chang, 2002; Sharma and Minhas, 2005; Qadir et al., 2007). The remediation of salt-affected soil using chemical agents, including gypsum $\left(\mathrm{CaSO}_{4} \cdot 2 \mathrm{H}_{2} \mathrm{O}\right)$, calcite $\left(\mathrm{CaCO}_{3}\right)$, calcium chloride $\left(\mathrm{CaCl}_{2} \cdot 2 \mathrm{H}_{2} \mathrm{O}\right)$, and organic matter (farmyard manure, green manure, organic amendment and municipal solid waste), is a successful approach that has been implemented worldwide, being effective, low cost, and simple (Mitchell et al., 2000; Hanay et al., 2004; Sharma and Minhas, 2005; Tejada et al., 2006). The physical, chemical and biological properties of soil in salt-affected areas are improved by the application of OM, leading to enhanced plant growth and development. Therefore, the application of OM for soil remediation is important for sustainable land use and crop productivity (Choudhary et al., 2004; Wong et al., 2009).

Rice (Oryza sativa L. spp. indica) is one of the five main carbohydrate crops responsible for feeding the world's popu- lation, and is especially important in Asian countries. It plays a major role as a staple food, supporting more than 3 billion people and comprising 50-80\% their daily calorie intake (Khush, 2005). Rice has previously been reported as being salt susceptible in both the seedling and reproductive stages (Zeng et al., 2001; Moradi and Ismail, 2007), leading to a reduction in yield of more than $50 \%$ in crops exposed to $6.65 \mathrm{dS} \mathrm{m}^{-1}$ ECe (Zeng and Shannon, 2000). RD6 is a mutant line derived from jasmine rice (non-glutinous cv. KDML105) irradiated with gamma radiation and is the dominant rice cultivar in the rain-fed lowland area of Thailand. It is a premium quality glutinous rice, in terms of aroma, cooking quality, sticky texture and long grains (Keeratipibul et al., 2008) and is widely cultivated in the Northeast region of Thailand, which is reported as being affected by soil salinity (Wongpokhom et al., 2008). The aim of the present study was to remediate saline soil using organic matter $(\mathrm{OM})$ before the cultivation of $\mathrm{RD} 6$ rice, prior to grain harvesting.

\section{Materials and Methods}

For the nursery stock to be raised, seeds of rice cultivar RD6 were allowed to germinate and then transplanted to pots containing clay soil in 50\% shading (acclimatization) light intensity for one month. Pots were placed on plastic trays $(0.30 \times 0.45 \mathrm{~m})$, with 72 pots per tray. Irrigation was applied as water spray. One hundred acclimatized plants were transplanted directly to saline paddy fields $\left(4 \mathrm{~m}^{2}\right.$ with $0.20 \times 0.20$ $\mathrm{m}$ plant to plant and row to row distance) at four sites (0.0,

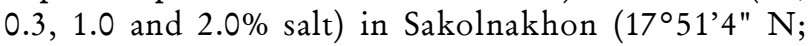
$\left.103^{\circ} 34^{\prime} 12^{\prime \prime} \mathrm{E}\right)$, Northeast of Thailand (Table 1). Green manure $(\mathrm{GM})$ and farmyard manure $(\mathrm{FYM})$, in a ratio $1: 1$ (w/ 
Table 1 - Salinity level, electrical conductivity $\left(\mathrm{EC}_{\mathrm{e}}\right)$, soil $\mathrm{pH}$, nitrogen $(\mathrm{N})$, phosphorus $(\mathrm{P})$ and potassium $(\mathrm{K})$ in the studied sites, in the Northern region of Thailand.

\begin{tabular}{|c|c|c|c|c|c|c|}
\hline Plot site & Salt level & $\mathrm{EC}_{\mathrm{e}}$ & $\mathrm{pH}$ & \multicolumn{3}{|c|}{ Available form of nutrients } \\
\hline & $\%$ & $\mathrm{dS} \mathrm{m}^{-1}$ & & $\mathrm{~N}\left(\mathrm{~g} \mathrm{~kg}^{-1}\right)$ & $\mathrm{P}\left(\mathrm{mg} \mathrm{kg}^{-1}\right)$ & $\mathrm{K}\left(\mathrm{g} \mathrm{kg}^{-1}\right)$ \\
\hline I & 0 & 1.0 & 5.49 & 0.61 & 8.17 & 6.47 \\
\hline II & 0.3 & 2.6 & 4.73 & 0.38 & 2.08 & 2.00 \\
\hline III & 1.0 & 8.5 & 4.58 & 0.27 & 1.72 & 2.33 \\
\hline IV & 2.0 & 20.4 & 4.79 & 0.52 & 12.95 & 4.00 \\
\hline
\end{tabular}

$\mathrm{w})$, were mixed together and then applied to the soil as organic matter $(\mathrm{OM})$, at $12.5 \mathrm{~kg} \mathrm{~m}^{-2}$, compared to the control (without OM). Chemical fertilizer (16:16:16; Nitrogen: Phosphorus: Potassium) was applied three times, in mid-August, September and October at $0.0156 \mathrm{~kg} \mathrm{~m}^{-2}$, prior to the flowering stage. Photosynthetic pigments, chlorophyll a fluorescence and net photosynthetic rate $\left(P_{\mathrm{n}}\right)$ in the flag leaf were assayed. In addition, data on plant height, number of leaves, number of tillers, leaf area, spike length, spike weight, onehundred seed weight, and total grain weight per clump were recorded in the harvesting period.

Chlorophyll $a\left(\mathrm{Chl}_{\mathrm{a}}\right)$, chlorophyll $b\left(\mathrm{Chl}_{\mathrm{b}}\right)$ and total chlorophyll (TC) concentrations were determined following the method of Shabala et al. (1998) and the total carotenoids $\left(\mathrm{C}_{\mathrm{x}+\mathrm{c}}\right)$ concentration was measured according to Lichtenthaler (1987). One hundred milligrams of leaf material was collected, placed in a $25 \mathrm{~mL}$ glass vial along with $10 \mathrm{~mL}$ of $95.5 \%$ acetone, and blended using a homogenizer. $\mathrm{Chl}_{a}, \mathrm{Chl}_{b}$, and $\mathrm{C}_{x+c}$ concentrations were measured using an UV-visible spectrophotometer. A solution of $95.5 \%$ acetone was used as a blank.

Chlorophyll a fluorescence emission from the adaxial surface of leaf was monitored with a Fluorescence Monitoring System (FMS 2; Hansatech Instruments Ltd., Norfolk, UK) in the pulse amplitude modulation mode, as previously described by Loggini et al. (1999) and Maxwell and Johnson (2000). Net photosynthetic rate $\left(P_{n}\right)$ was measured using a Portable Photosynthesis System with an Infra-red Gas Analyser (IRGA; Model LI 6400, LI-COR ${ }^{\circledR}$ Inc, Lincoln, Nebraska, USA) according to Cha-um et al. (2007).

Plant height, number of leaves, number of tillers, leaf area, spike length, spike weight, one-hundred seed weight, and total grain weight per clump were measured. Leaf area was determined using a Leaf Area Meter DT-scan (Delta-Scan Version 2.03, Delta-T Devices, Ltd., Burwell, Cambridge, UK).

The experiment was arranged as $4 \times 2$ factorial in Completely Randomized Design (CRD) with ten replicates $(\mathrm{n}=$ 10). Analysis of variance $(A N O V A)$ in each parameter was analyzed. The mean values were compared using Tukey-B test and analyzed with SPSS software (SPSS for Windows, SPSS Inc., Chicago, USA). The correlations between physiological and morphological parameters were evaluated by Pearson's correlation coefficients.

\section{Results and Discussion}

The chlorophyll $a(\mathrm{Chl})$ content in the leaf tissue of $\mathrm{RD} 6$ rice grown in salt affected soil decreased, by 5.4, 19.6 and $26.4 \%$, when exposed to $0.3,1.0$ and $2.0 \%$ salt levels, respectively. Chlorophyll $b\left(\mathrm{Chl}_{\mathrm{b}}\right)$, total chlorophyll (TC) and total carotenoids $\left(\mathrm{C}_{\mathrm{x}+\mathrm{c}}\right)$ content had a similar trend to that of $\mathrm{Chl}_{\mathrm{a}}$. The $\mathrm{Chl}$ a content in salt stressed leaves of $\mathrm{RD} 6$ rice was stabilized in the saline soil treated by OM, especially in the 1-2\% salt levels (Table 2). TC pigments in rice plants grown with $\mathrm{OM}$ treatment in $2 \%$ salt levels were maintained better than in the control (without OM) (Table 2). Photosynthetic pigment contents in the leaves of salt-stressed rice plants were decreased, depending on increasing salt levels in the soil. The Chl content in the salt stressed leaves was positively related to maximum quantum yield of PSII $\left(\mathrm{F}_{\mathrm{v}} / \mathrm{F}_{\mathrm{m}}\right)$ $\left(\mathrm{r}^{2}=0.80\right)$ (Figure 1A). $\mathrm{F}_{\mathrm{v}} / \mathrm{F}_{\mathrm{m}}$ dropped, relating to salt concentration in the soil (Table 3). Quantum efficiency of PSII $\left(\Phi_{\mathrm{PSII}}\right)$ in the salt-stressed leaves declined by $1.5,5.3$ and $12.7 \%$ when exposed to $0.3,1.0$ and $2.0 \%$ salt levels, respectively. The $\Phi_{\text {PSII }}$ in salt stressed leaves of RD6 rice was improved in the saline soil treated by organic matter $(\mathrm{OM})$, especially in the $2.0 \%$ salt levels (Table 3 ). A positive relationship between $\mathrm{F}_{\mathrm{v}} / \mathrm{F}_{\mathrm{m}}$ and $\Phi_{\text {PSII }}$ was displayed $\left(\mathrm{r}^{2}=0.59\right)(\mathrm{Fig}-$ ure 1B) which subsequently affected the net photosynthetic rate $\left(P_{\mathrm{n}}\right)\left(\mathrm{r}^{2}=0.46\right)$ (Figure $\left.2 \mathrm{~A}\right) . P_{\mathrm{n}}$, a sensitive parameter, reduced drastically, by $26.2,26.7$ and $33.3 \%$ when subjected to $0.3,1.0$ and $2.0 \%$ salt levels, respectively (Table 3 ). In con-
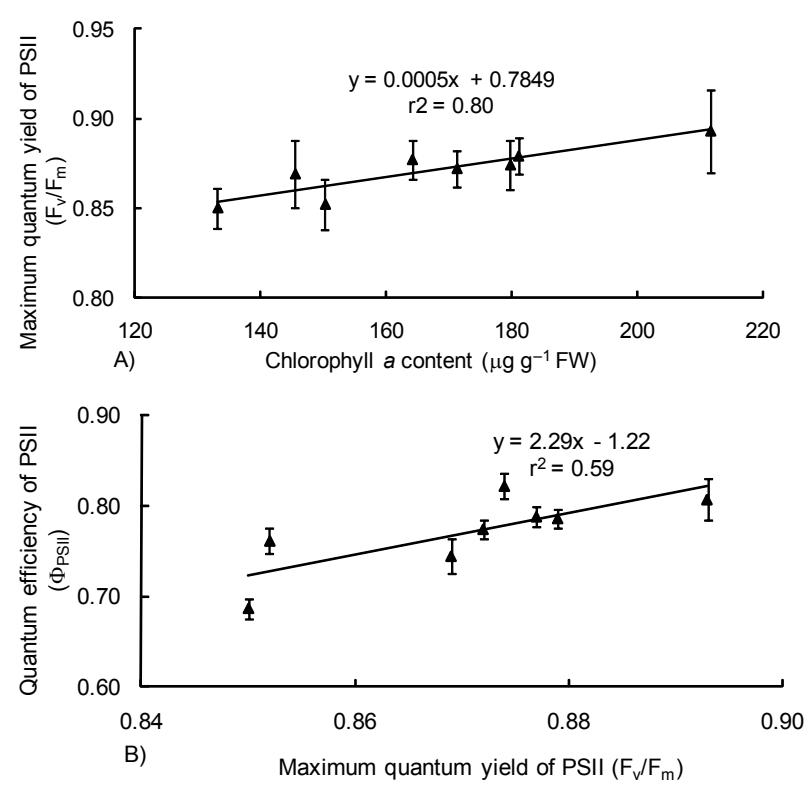

Figure 1 - Relationships between chlorophyll $a(\mathrm{Chl})$ content and maximum quantum yield of PSII $\left(\mathrm{F}_{\mathrm{v}} / \mathrm{F}_{\mathrm{m}}\right)(\mathrm{A})$ and $\mathrm{F}_{\mathrm{v}} / \mathrm{F}_{\mathrm{m}}$ and quantum efficiency of PSII $\left(\Phi_{\mathrm{PSII}}\right)(\mathrm{B})$ in leaf tissues of glutinous rice (cv. RD6) cultivated in field trials with salinity and remediation procedures. 
trast, $P_{\mathrm{n}}$ in $\mathrm{OM}$ treated plants was sustained to a greater degree than in plants grown without $\mathrm{OM}(19.0,22.3$ and $22.8 \%)$, leading to high productivity as indicated by total grain weight per clump $\left(r^{2}=0.45\right)$ (Figure $\left.2 \mathrm{~B}\right)$. Overall growth performance, demonstrated by plant height, number of leaves and leaf area, was evidently retarded in plants grown in $1.0-2.0 \%$ salt levels, especially in those without OM (control) treatment (Table 4). In contrast, the growth

Table 2 - Chlorophyll $a\left(\mathrm{Chl}_{\mathrm{z}}\right)$, chlorophyll $b\left(\mathrm{Chl}_{\mathrm{b}}\right)$, total chlorophyll (TC) and total carotenoids $\left(\mathrm{C}_{\mathrm{x}+\mathrm{c}}\right)$ in the leaf tissues of glutinous rice (cv. RD6) cultivated in field trials with different salinity and remediation procedures.

\begin{tabular}{|c|c|c|c|c|c|}
\hline Salt level & Remediation & Chl & $\mathrm{Chl}_{\mathrm{b}}$ & TC & $C_{x+c}$ \\
\hline$\%$ & \multicolumn{5}{|c|}{ 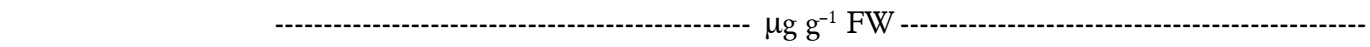 } \\
\hline \multirow[t]{2}{*}{0} & Control & $181.1 \mathrm{~b}$ & $48.2 \mathrm{~b}$ & $229.3 \mathrm{~b}$ & $62.4 \mathrm{ab}$ \\
\hline & $\mathrm{OM}$ & $211.7 \mathrm{a}$ & $71.7 \mathrm{a}$ & $283.4 \mathrm{a}$ & $68.3 \mathrm{a}$ \\
\hline \multirow[t]{2}{*}{0.3} & Control & $171.3 \mathrm{bc}$ & $44.2 \mathrm{bc}$ & $215.5 \mathrm{bc}$ & $60.5 \mathrm{bc}$ \\
\hline & $\mathrm{OM}$ & $179.8 \mathrm{~b}$ & $45.7 \mathrm{bc}$ & $225.5 \mathrm{~b}$ & $60.8 \mathrm{bc}$ \\
\hline \multirow[t]{2}{*}{1.0} & Control & 145.5 de & $39.0 \mathrm{~cd}$ & $184.5 \mathrm{de}$ & $50.8 \mathrm{de}$ \\
\hline & $\mathrm{OM}$ & $164.2 \mathrm{bc}$ & $43.6 \mathrm{bc}$ & $207.8 \mathrm{~cd}$ & $53.4 \mathrm{~cd}$ \\
\hline \multirow[t]{2}{*}{2.0} & Control & $133.2 \mathrm{e}$ & $32.9 \mathrm{~d}$ & $166.1 \mathrm{e}$ & $45.6 \mathrm{e}$ \\
\hline & $\mathrm{OM}$ & $150.3 \mathrm{~cd}$ & $38.1 \mathrm{~cd}$ & $188.4 \mathrm{~cd}$ & $52.7 \mathrm{de}$ \\
\hline$A N O V A$ & & $* *$ & $* * *$ & $* *$ & $* *$ \\
\hline
\end{tabular}

Significant at $p \leq 0.01$ is represented by $* *$ Means followed by the different letters are different (Tukey-B test, $p \leq 0.01$ ).

Table 3 - Maximum quantum efficiency of PSII $\left(\mathrm{F}_{\mathrm{v}} / \mathrm{F}_{\mathrm{m}}\right)$, quantum efficiency of PSII $\left(\Phi_{\text {PSII }}\right)$ and net photosynthetic rate $\left(P_{\mathrm{n}}\right)$ in leaf tissues of glutinous rice (cv. RD6) cultivated in field trials with salinity and remediation procedures.

\begin{tabular}{lcccc}
\hline Salt level & Remediation & $\mathrm{F}_{\mathrm{v}} / \mathrm{F}_{\mathrm{m}}$ & $\Phi_{\text {SII }}$ & $P_{\mathrm{n}}$ \\
\hline$\%$ & & & & $\mu \mathrm{mol} \mathrm{m}^{-2} \mathrm{~s}^{-1}$ \\
0 & Control & $0.879 \mathrm{ab}$ & $0.786 \mathrm{bc}$ & $17.1 \mathrm{a}$ \\
& OM & $0.893 \mathrm{a}$ & $0.807 \mathrm{ab}$ & $17.5 \mathrm{a}$ \\
0.3 & Control & $0.872 \mathrm{ab}$ & $0.774 \mathrm{bc}$ & $12.7 \mathrm{~b}$ \\
& OM & $0.874 \mathrm{ab}$ & $0.822 \mathrm{a}$ & $14.2 \mathrm{ab}$ \\
1.0 & Control & $0.869 \mathrm{ab}$ & $0.744 \mathrm{c}$ & $12.6 \mathrm{~b}$ \\
& OM & $0.877 \mathrm{ab}$ & $0.788 \mathrm{bc}$ & $13.6 \mathrm{~b}$ \\
& Control & $0.850 \mathrm{~b}$ & $0.686 \mathrm{~d}$ & $11.4 \mathrm{~b}$ \\
\hline ANOVA & OM & $0.852 \mathrm{ab}$ & $0.761 \mathrm{bc}$ & $13.5 \mathrm{~b}$ \\
\hline
\end{tabular}

Significant at $p \leq 0.01$ and significant at $p \leq 0.05$ are represented by $* *$ and $*$, respectively. Means followed by the different letters are different at $p \leq 0.05$ and $p \leq 0.01$ by Tukey-B test.

Table 4 - Plant height, number of leaves and leaf area of glutinous rice (cv. RD6) cultivated in field trials with salinity and remediation procedures.

\begin{tabular}{lcccc}
\hline Salt level & Remediation & Plant height & Number of leaves & Leaf are \\
\hline$\%$ & & $\mathrm{~cm}$ & & $\mathrm{~cm}^{2}$ \\
0 & Control & $136.0 \mathrm{a}$ & $4.7 \mathrm{a}$ & $191.2 \mathrm{~b}$ \\
& OM & $139.3 \mathrm{a}$ & $4.8 \mathrm{a}$ & $273.4 \mathrm{a}$ \\
0.3 & Control & $118.2 \mathrm{bc}$ & $4.0 \mathrm{ab}$ & $180.1 \mathrm{~b}$ \\
1.0 & OM & $128.6 \mathrm{ab}$ & $4.5 \mathrm{ab}$ & $217.5 \mathrm{ab}$ \\
& Control & $104.4 \mathrm{~cd}$ & $3.9 \mathrm{ab}$ & $161.4 \mathrm{~b}$ \\
2.0 & OM & $127.8 \mathrm{ab}$ & $4.1 \mathrm{ab}$ & $209.8 \mathrm{~b}$ \\
\hline ANOVA & Control & $84.9 \mathrm{e}$ & $3.6 \mathrm{~b}$ & $89.3 \mathrm{c}$ \\
\hline
\end{tabular}

Significant at $p \leq 0.01$ is represented by $* *$. Means followed by the different letters are different at $p \leq 0.01$ by Tukey-B test. 
Table 5 - Number of tillers, spike length, spiklet weight and 100-seed weight of glutinous rice (cv. RD6) cultivated in field trials with salinity and remediation procedures.

\begin{tabular}{|c|c|c|c|c|c|}
\hline Salt level & Remediation & Number of tillers & Spike length & Spike weight & 100-seed weight \\
\hline$\%$ & & & $\mathrm{~cm}$ & 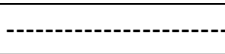 & 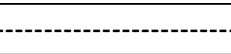 \\
\hline \multirow[t]{2}{*}{0} & Control & $11.8 \mathrm{bc}$ & $25.2 \mathrm{~b}$ & $3.1 \mathrm{bc}$ & $2.55 \mathrm{bcd}$ \\
\hline & $\mathrm{OM}$ & $13.6 \mathrm{ab}$ & $25.9 \mathrm{~b}$ & $3.7 \mathrm{ab}$ & $2.71 \mathrm{ab}$ \\
\hline \multirow[t]{2}{*}{0.3} & Control & $9.3 \mathrm{~cd}$ & $25.2 \mathrm{~b}$ & $3.0 \mathrm{bc}$ & $2.80 \mathrm{a}$ \\
\hline & $\mathrm{OM}$ & $15.4 \mathrm{a}$ & $27.3 \mathrm{a}$ & $4.4 \mathrm{a}$ & $2.79 \mathrm{a}$ \\
\hline \multirow[t]{2}{*}{1.0} & Control & $7.9 \mathrm{~d}$ & $23.5 \mathrm{c}$ & $2.5 \mathrm{c}$ & $2.70 \mathrm{ab}$ \\
\hline & $\mathrm{OM}$ & $10.0 \mathrm{c}$ & $26.4 \mathrm{ab}$ & $4.4 \mathrm{a}$ & $2.76 \mathrm{ab}$ \\
\hline \multirow[t]{2}{*}{2.0} & Control & $6.6 \mathrm{~d}$ & $23.9 \mathrm{c}$ & $2.6 \mathrm{c}$ & $2.45 \mathrm{~d}$ \\
\hline & $\mathrm{OM}$ & $9.1 \mathrm{~cd}$ & $24.7 \mathrm{bc}$ & $2.7 \mathrm{c}$ & $2.52 \mathrm{~cd}$ \\
\hline$A N O V A$ & & $* *$ & $* *$ & $* *$ & $* *$ \\
\hline
\end{tabular}

Significant at $p \leq 0.01$ is represented by $* *$. Means followed by the different letters are different at $p \leq 0.01$ by Tukey-B test.
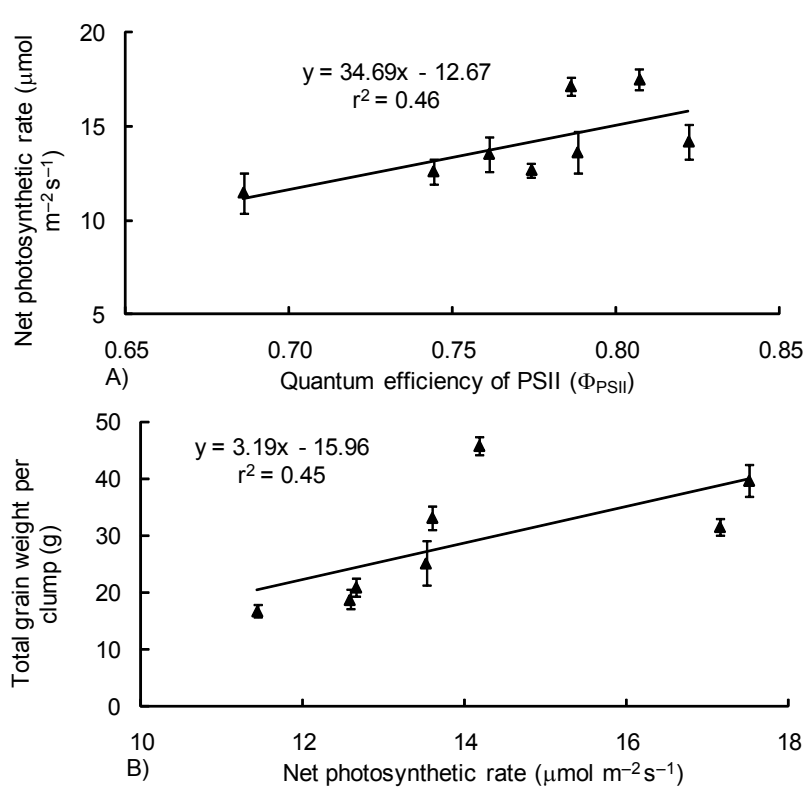

Figure 2 - Relationships between quantum efficiency of PSII $\left(\Phi_{\mathrm{PSI}}\right)$ and net photosynthetic rate $\left(P_{\mathrm{n}}\right)(\mathrm{A})$ and $P_{\mathrm{n}}$ and total grain weight $(\mathrm{B})$ of glutinous rice (cv. RD6) cultivated in field trials with salinity and remediation procedures.

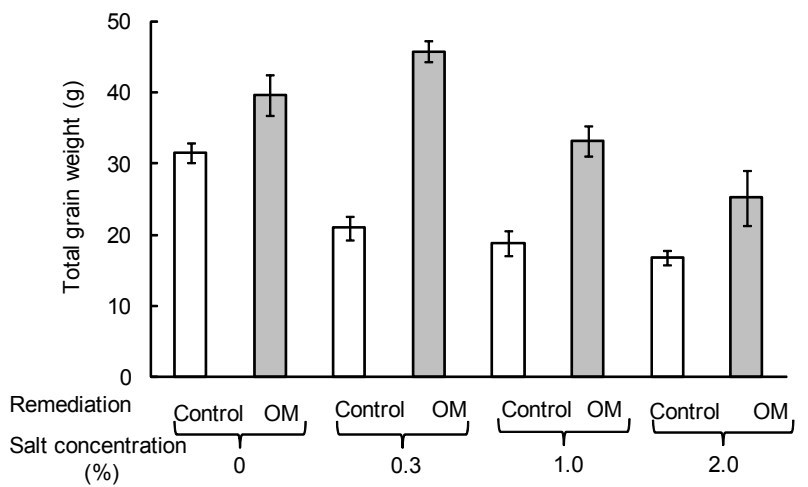

Figure 3 - Total grain weight per clump of glutinous rice (cv. RD6) cultivated in field trials with salinity and remediation procedures. characters of OM treated plants were an improvement, except in the case of extreme salt contamination ( $2 \%$ salt level). Overall, salt stress adversely affected yield traits, including number of tillers, spike length, spike weight and 100-seed weight (Table 5), as well as total grain weight (TGW) (Figure 3).

Levels of Chl and TC pigments in rice grown in saline soil ( $2 \%$ salt level) treated with OM were maintained better than in the control (without OM treatment), leading to a high water oxidation rate in photosystem II and high $P_{\mathrm{n}}$, and subsequently high productivity. In Hordeum maritimum, the photosynthetic pigments $\mathrm{Chl}, \mathrm{Chl}_{\mathrm{b}}$ and TC in plants cultivated in saline water treatment $\left(4 \mathrm{~g} \mathrm{~L}^{-1} \mathrm{NaCl}\right)$ with municipal solid waste (MSW) application $\left(40 \mathrm{tha}^{-1}\right)$ were stabilized better than in the control (without MSW) by 48, 49 and $48 \%$, respectively (Lakhdar et al., 2008). Organic matter $(\mathrm{OM})$, including farmyard manure (FYM) and green manure (GM), may function as salt ion binding agents which detoxify the toxic ions, especially $\mathrm{Na}^{+}$and $\mathrm{Cl}^{-}$, as indicated by low EC in soil treated with OM (Zaka et al., 2003; Hanay et al., 2004; Tejada et al., 2006; Zahid and Niazi, 2006). In the case of rice, remediation of saline paddy fields using OM improved productivity in the reproductive stage (Qadir et al., 2001; Zaka et al., 2003; Amanullah, 2008; Ghafoor et al., 2008; Murtaza et al., 2009). The most serious cases of yield reduction in crops grown in saline paddy fields that have not undergone remediation, are a subsequent effect of toxic ion accumulation in the plant cells, which causes pigment reduction, diminishes chlorophyll $a$ fluorescence and lowers $P_{\mathrm{n}}$. There are many reports on rice cultivation which clearly demonstrate the relationship between physiological and morphological changes in reproductive development during seed set, when plants are exposed to salt-affected soil without remediation (Zeng and Shannon, 2000; Zeng et al., 2003; Ali et al., 2004). OM application to saline paddy soil is an effective remediation procedure, in terms of the physical, chemical and biological properties of the soil (Mitchell et al., 2000; Hanay et al., 2004; Tejada et al., 2006; Wong et al., 2009), which can be used to enhance the growth and development of rice crops prior to grain harvesting (Ghafoor et al., 2008; Murtaza et al., 2009). 
In conclusion, the level of chlorophyll $a$ and total chlorophyll pigments in RD6 rice grown in saline soil (2\% salt level) treated with OM was higher than in the control (without $\mathrm{OM})$, resulting in improved photosynthetic abilities. Net-photosynthetic rate $\left(P_{\mathrm{n}}\right)$ in the salt-stressed leaves was strongly related to total grain weight, so, OM treatment in paddy fields could effectively alleviate the problem of soil salinity, resulting in yield improvement.

\section{Acknowledgements}

To the Siam Cement Group (SCG) as a funding source, the partial support by the National Center for Genetic Engineering and Biotechnology (BIOTEC) (Grant number; BT-B02-RG-BC-4905) and Dr. Teeraporn Busaya-angoon of the Pathumthani Rice Research Center, for providing RD6 rice seed.

\section{References}

Ahmad, R.; Chang, M.H. 2002. Salinity control and environmental protection through halophytes. Journal of Drainage and Water Management 6: 17-25.

Ali, Y.; Aslam, Z.; Ashraf, M.Y.; Tahir, G.R. 2004. Effect of salinity on chlorophyll concentration, leaf area, yield and yield components of rice genotypes grown under saline environment. International Journal of Environmental Science and Technology 1: 221-225.

Amanullah, M.M. 2008. Response of lowland rice varieties to reclamation practices in coastal saline soils. Journal of Applied Science Research 4: 871-874.

Cha-um, S.; Supaibulwatana, K.; Kirdmanee, C. 2007. Glycinebetaine accumulation, physiological characterizations, and growth efficiency in salt tolerant and salt sensitive lines of indica rice (Oryza sativa L. spp. indica) response to salt stress. Journal of Agronomy and Crops Science 193: 157-166.

Chinnusamy, V.; Jagendorf, A.; Zhu, J.K. 2005. Understanding and improving salt tolerance in plants. Crop Science 45: 437-448.

Choudhary, O.P.; Josan, A.S.; Bajwa, M.S.; Kapur, L. 2004. Effect of sustained sodic and saline-sodic irrigation and application of gypsum and farmyard manure on yield and quality of sugarcane under semi-arid conditions. Field Crops Research 87: 103-116.

Ghafoor, A.; Murtaza, G.; Ahmad, B.; Boers, T.M. 2008. Evaluation of amelioration treatments and economic aspects of using salinesodic water for rice and wheat production on salt-affected soils under arid land conditions. Irrigation and Drainage 57: 424-434.

Hanay, A.; Büyüksönmez, F.; Kiziloglu, F.M.; Canbolat, M.Y. 2004. Reclamation of saline-sodic soils with gypsum and MSW compost. Compost Science and Utilization 12: 175-179.

Hasegawa, P.M.; Bressan, R.A.; Zhu, J.K.; Bohnert, H.J. 2000. Plant cellular and molecular responses to high salinity. Annual Review of Plant Physiology and Molecular Biology 51: 463-499.

Keeratipibul, S.; Luangsakul, N.; Lertsatchayarn, T. 2008. The effect of Thai glutinous rice cultivars, grain length and cultivating locations on the quality of rice cracker (arare). LWT-Food Science and Technology 41: 1934-1943.

Khush, G.S. 2005. What it will take to feed 5.0 billion rice consumers in 2030. Plant Molecular Biology 59: 1-6.

Lakhdar, A.; Hafsi, C.; Rabhi, M.; Debez, A.; Montemurro, F.; Abdelly, C.; Jedidi, N.; Ouerghi, Z. 2008. Application of municipal solid waste compost reduces the negative effects of saline water in Hordeum maritimum L. Bioresource Technology 99: 7160-7167.

Lichtenthaler, H.K. 1987. Chlorophylls and carotenoids: Pigments of photosynthetic biomembranes. Methods in Enzymology 148: 350-380.
Loggini, B.; Scartazza, A.; Brugnoli, E.; Navari-Izzo, F. 1999. Antioxidant defense system, pigment composition, and photosynthetic efficiency in two wheat cultivars subjected to drought. Plant Physiology 119: 1091-1099.

Mansour, M.M.F.; Salama, K.H.A. 2000. Cellular basis of salinity tolerance in plants. Environmental and Experimental of Botany 52: 113-122.

Maxwell, K.; Johnson, G.N. 2000. Chlorophyll fluorescence: a practical guide. Journal of Experimental Botany 51: 659-668.

Mitchell, J.P.; Shennan, C.; Singer, M.J.; Peters, D.W.; Miller, R.O.; Prichard, T.; Grattan, S.R.; Rhoades, J.D.; May, D.M.; Munk, D.S. 2000. Impacts of gypsum and winter cover crops on soil physical properties and crop productivity when irrigated with saline water. Agricultural Water Management 45: 55-71.

Moradi, F.; Ismail, A.M. 2007. Responses of photosynthesis, chlorophyll fluorescence and ROS-Scavenging systems to salt stress during seedling and reproductive stages in rice. Annals of Botany 99: 1161-1173

Murtaza, G.; Ghafoor, A.; Owens, G.; Qadir, M.; Kahlon, U.Z. 2009. Environmental and economic benefits of saline-sodic soil reclamation using low-quality water and soil amendments in conjunction with a rice-wheat cropping system. Journal of Agronomy and Crops Science 195: 124-136.

Qadir, M.; Oster, J.D.; Schubert, S.; Noble, A.D.; Sahrawat, K.L. 2007. Phytoremediation of sodic and saline-sodic soils. Advances in Agronomy 96: 197-247.

Qadir, M.; Ghafoor, A.; Murtaza, G. 2001. Use of saline-sodic waters through phytoremediation of calcareous saline-sodic soils. Agricultural Water Management 50: 197-210.

Shabala, S.N.; Shabala, S.I.; Martynenko, A.I.; Babourina, O.; Newman, I.A. 1998. Salinity effect on bioelectric activity, growth, $\mathrm{Na}^{+}$ accumulation and chlorophyll fluorescence of maize leaves: a comparative survey and prospects for screening. Australian Journal of Plant Physiology 25: 609-616.

Sharma, B.R.; Minhas, P.S. 2005. Strategies for managing saline/alkali waters for sustainable agricultural production in South Asia. Agricultural Water Management 78: 136-151.

Tanji, K.K. 2002. Salinity in the soil environment. p. 21-51. In: Lauchli A.; Luttge U., eds. Salinity environment-plant - molecules. Kluwer Academic, Dordrecht, The Netherlands.

Tejada, M.; Garcia, C.; Gonzalez, J.L.; Hernandez, M.T. 2006. Use of organic amendment as a strategy for saline soil remediation: Influence on the physical, chemical and biological properties of soil. Soil Biology and Biochemistry 38: 1413-1421.

Wong, V.N.L.; Dalal, R.C.; Greene, R.S.B. 2009. Carbon dynamics of sodic and saline soil following gypsum and organic material additions: A Laboratory Incubation. Applied Soil Ecology 41: 29-40.

Wongpokkhom, N.; Kheoruenromne, I.; Suddhiprakarn, A.; Gilkes, R.J. 2008. Micromorphological properties of salt affected soils in Northeast Thailand. Geoderma 144: 158-170.

Zahid, L.; Niazi, M.F.K. 2006. Role of ristech material in the reclamation of saline-sodic soils. Pakistan Journal of Water Resources 10: 43 49.

Zaka, M.A.; Mujeeb, F.; Sarwar, G.; Hassan, N.M.; Hassan, G. 2003. Agromelioration of saline sodic soil. OnLine Journal of Biological Science 3: 329-334.

Zang, L.; Shannon, M.C.; Lesch, S.M. 2001. Timing of salinity stress affects rice growth and yield components. Agricultural Water Management 48: 191-206.

Zeng, L.; Shannon, M.C. 2000. Salinity effects on seedling growth and yield components of rice. Crop Science 40: 996-1003.

Zeng, L.; Lesch, S.M.; Grieve, C.M. 2003. Rice growth and yield respond to changes in water depth and salinity stress. Agricultural Water Management 59: 67-75.

Received March 18, 2010

Accepted November 11, 2010 